\title{
Using Rule 9(b) to Reduce Nuisance Securities Litigation
}

\author{
William C. Baskin III
}

In the fifty-one years since the Federal Rules of Civil Procedure were enacted to "secure the just, speedy, and inexpensive determination of every action," the landscape of Federal civil litigation" has changed dramatically. Technological innovations ${ }^{3}$ and evolving attitudes in society and the bar have transformed the number and types of cases brought and pursued in Federal courts. ${ }^{4}$ In contrast to this dynamic legal environment, several of the Federal Rules, or portions of them, have remained static. Consequently, judicial constructions of these Rules have evolved to take into account the changing nature of the disputes they regulate.

One such evolution involves rule $9(\mathrm{~b})$, which governs the pleading of

1. FED. R. Civ. P. 1 .

2. Discussion in this Note is limited to the Federal legal system. While much of the analysis applies to state legal systems as well, they are beyond the scope of this Note.

3. Since 1938, new technologies such as photocopying machines, word processors, computerized litigation support systems, on-line databases, telefacsimile machines, and overnight delivery services have revolutionized the practice of law. Tasks such as drafting and filing a brief that once took weeks now take days or hours. For example, at the time the Federal Rules were initially drafted it might have been physically impossible to pursue an action the size of the IBM antitrust litigation or the Washington Public Power Supply System bond default litigation. Today, these "megacases," involving several hundred thousand documents and/or hundreds of plaintiffs, while not routine, are at least manageable.

4. For example, private securities fraud claims were virtually unknown at the time the Federal Rules were adopted. The first case recognizing a private cause of action for damages under $\S 10(\mathrm{~b})$ of the Securities and Exchange Act of 1934, 15 U.S.C. \$ 78j(b) (1982), and rule 10b-5 promulgated thereunder, 17 C.F.R. $\$ 240.10$ b-5 (1987), was Kardon v. National Gypsum Co., 69 F. Supp. 512 (E.D. Pa. 1946). These cases have since multiplied and grown into a "judicial oak." Blue Chip Stamps v. Manor Drug Stores, 421 U.S. 723, 737 (1975). 
fraud, mistake, and condition of the mind. ${ }^{5}$ In 1979, the Court of Appeals for the Second Circuit began requiring plaintiffs in securities actions brought pursuant to section 10(b) of the Securities and Exchange Act of $1934^{6}$ and rule $10 \mathrm{~b}-5$ promulgated thereunder ${ }^{7}$ to plead scienter ${ }^{8}$ with particularity pursuant to rule $9(\mathrm{~b}) .^{9}$ The principal result of this requirement has been to permit district courts within the Second Circuit to dismiss nuisance suits ${ }^{10}$ on the basis of the complaint alone. Other circuits have declined to follow the Second Circuit, ${ }^{11}$ and several scholars and commentators have argued against this use of rule $9(\mathrm{~b}) .{ }^{\mathbf{1 2}}$

This Note argues that, with a slight modification, the Second Circuit's interpretation of rule $9(\mathrm{~b})$ is a narrowly tailored response to section $10(\mathrm{~b})$ and rule $10 \mathrm{~b}-5$ nuisance litigation, and should be adopted nationally. ${ }^{13}$ Part I describes rule 9(b)'s particularity requirement and documents the split in the circuits. Part II discusses the theoretical reasons for the existence of nuisance litigation and explains why securities law is particularly

5. FED. R. Crv. P. 9(b) provides: "In all averments of fraud or mistake, the circumstances constituting fraud or mistake shall be stated with particularity. Malice, intent, knowledge, and other conditions of mind of a person may be averred generally."

6. 15 U.S.C. $\$ 78 \mathrm{j}(\mathrm{b})(1982)$.

7. 17 C.F.R. § $240.10 b-5$ (1987).

8. Scienter is "a mental state embracing intent to deceive, manipulate, or defraud." Ernst \& Ernst v. Hochfelder, 425 U.S. 185, 194 n.12 (1976). "IS J cienter is an element of a violation of $\$ 10(b)$ and Rule $10 \mathrm{~b}-5$, regardless of the identity of the plaintiff or the nature of the relief sought." Aaron v. SEC, 446 U.S. 680, 691 (1980); Hochfelder, 425 U.S. at $192 \mathrm{n.7,193}$ (scienter is an essential element of cause of action for damages under $\$ 10(\mathrm{~b})$ and "rule $10 \mathrm{~b}-5)$.

9. Ross v. A.H. Robins Co., 607 F.2d 545, 558 (2d Cir. 1979), cert. denied, 446 U.S. 946 (1980). The Ross court held that, although plaintiffs cannot reasonably be expected to plead defendant's actual knowledge before discovery, the first sentence of rule $9(\mathrm{~b})$ ("circumstances constituting fraud . . . shall be stated with particularity") requires plaintiffs "to supply a factual basis for their conclusory allegations regarding [defendant's scienter]" in the complaint. Id. The Second Circuit thus allows plaintiffs to aver scienter generally as required by the second sentence of rule $9(\mathrm{~b})$, as long as they "specifically plead those events which they assert give rise to a strong inference that the defendants [acted with scienter]" in accordance with the first sentence of the rule. Id.

10. A "nuisance" or "strike" suit is an action "in which the plaintiff is able to obtain a positive settlement from the defendant even though the defendant knows the plaintiff's case is sufficiently" weak that he would be unwilling or unlikely actually to pursue his case to trial." Rosenberg \& Shavell, $A$ Model in Which Suits Are Brought for Their Nuisance Value, 5 INT'L REv. L. \& ECoN. 3, 3 (1985). It is an action that has a "settlement value independent of its merits." Coffee, Undersianding the Plaintiffs Attorney: The Implications of Economic Theony for Prizate Enforcement of Law' Through Class and Derizatize Actions, 86 Colum. L. Rev. 669, 669 n.1 (1986); see also Nazario, Hard Line Pays as Firm Fights Nuisance Suits, Wall St. J., Dec. 9, 1988, at B1, col. 6 (Standard Brands Paint Company "defines a nuisance lawsuit as a case that lacks merit but would cost more to defend than to settle").

11. See infra notes $19-23$.

12. Lees, Rule 9(b)-Who Needs It?, 3 J. ConTEMP. L. 105 (1976); Marcus, The Retival of Fact Pleading Under the Federal Rules of Citil Procedure, 86 Colum. L. REv. 433 (1986); Richman, Lively \& Mell, The Pleading of Fraud: Rhymps Without Reason, 60 S. CAL. L. REv. 959 (1987); Sovern, Reconsidering Federal Civil Rule 9(b): Do We Need Particularized Pleading Requirements in Fraud Cases?, 104 F.R.D. 143 (1985); Comment, Pleading Construciz'e Fraud in Securities Litigation-Aroiding Dismissal For Failure to Plead Fraud With Particularity, 33 EsORY L.J. 517 (1984); Note, Pleading Securities Fraud Claims With Particularity Under Rule 9(b), 97 HARV. L. REV. 1432 (1984).

13. While this Note focuses solely on claims and actions under $\$ 10(\mathrm{~b})$ and rule $10 \mathrm{~b}-5$, the analytic framework it employs could be applied to other instances where rule $9(b)$ is applicable and strong incentives for nuisance litigation exist. 
susceptible to this form of abuse. Part III addresses briefly the policy justifications for discouraging and dismissing nuisance actions. Part IV analyzes the opposing positions in terms of these policy considerations and proposes a limited discovery procedure that both incorporates the Second Circuit's interpretation of rule 9(b) and limits its inherent risk of dismissing meritorious suits.

\section{The Split in the Gircuits}

In 1976, the Supreme Court modified the substantive requirements for actions commenced and claims made under section 10(b) and rule 10b-5. In Ernst \& Ernst v. Hochfelder, the Court held that a private cause of action for damages under section 10(b) and rule 10b-5 will not lie "in the absence of any allegation [that the defendants acted with] 'scienter' intent to deceive, manipulate or defraud."14 While it did not examine the policy considerations underlying its action, the Court implied in dicta that a corollary purpose of the decision was to deter nuisance suits. ${ }^{15}$

The Hochfelder Court did not indicate the pleading standard to be applied to the new substantive scienter requirement. The circuits already had agreed that rule 9(b) applies to section $10(\mathrm{~b})$ and rule $10 \mathrm{~b}-5$ claims, since they are fraud-based. ${ }^{16}$ Moreover, virtually all circuits have applied a similar standard to the non-scienter allegations in section $10(\mathrm{~b})$ and rule $10 \mathrm{~b}-5$ claims based upon information and belief, requiring that such allegations be accompanied by a statement setting forth the facts upon which the belief is founded. ${ }^{17}$ However, the circuits have divided over the specificity with which a plaintiff must allege scienter. In averments of scienter, the Second Circuit requires plaintiffs to plead circumstances that "provide

14. Ernst \& Ernst v. Hochfelder, 425 U.S. 185, 192 n.7, 193 (1976); see supra note 8 (definition of scienter).

15. Hochfolder, 425 U.S. at 214-15 n.33 ("[W]e are not the first court to express concern that the inexorable broadening of the class of plaintiff who may sue [under $\S 10(\mathrm{~b})$ ] will ultimately result in more harm than good." (quoting Blue Chip Stamps v. Manor Drug Stores, 421 U.S. 723, 747-48 (1975)))

16. Ser, e.g., Tomera v. Gault, 511 F.2d 504, 508 (7th Gir. 1975); Walling v. Beverly Enters., 476 F.2d 393, 397 (9th Cir. 1973); Kellman v. ICS, Inc., 447 F.2d 1305, 1309 (6th Cir. 1971).

17. Stern v. Leucadia Nat'l Corp., 844 F.2d 997, 1003 (2d Cir.), cert. denied, 109 S. Ct. 137 (1988) (quotation of press speculation as to Leucadia's motives and press reports of other transactions in which Leucadia assertedly greenmailed other corporate targets not sufficient facts to support allegation that Leucadia never had any intention of acquiring target); Hayduk v. Lanna, 775 F.2d 441, 444 (1st Cir. 1985) (complaint contained no facts upon which plaintiff's belief could be founded); Semegen v. Weidner, 780 F.2d 727, 731 (9th Cir. 1985) (complaint lacked "specification of any times, dates, places or other details" of defendant's alleged involvement in fraudulent scheme); Wayne Inv., Inc. v. Gulf Oil Corp., 739 F.2d 11, 13-14 (1st Cir. 1984) (speculations of industry analysts that Gulf not conducting merger negotiations in good faith not sufficient facts to support allegation that Gulf fraudulently promised to use "best efforts" to consummate merger); Walling v. Beverly Enters., 476 F.2d at 397 (statement of time, place, and nature of alleged fraudulent activities satisfies requirements of rule 9(b)); Shemtob v. Shearson, Hammill \& Co., 448 F.2d 442, 444 (2d Cir. 1971) (mere conclusory allegations that defendant's conduct was fraudulent or in violation of rule $10 \mathrm{~b}-5$ not sufficient to satisly rule 9(b)); Duane v. Altenburg, 297 F.2d 515, 518 (7th Cir. 1962) (allegations of fraud made on information and belief must be accompanied by statement of facts upon which belief is founded). 
a factual foundation for otherwise conclusory allegations of scienter."18 The First, Third, Sixth, Ninth, and Tenth Circuits apply a more relaxed standard. The First Circuit has held that " $t$ t]he clear weight of authority is that Rule 9 requires specification of the time, place, and content of an alleged false representation, but not the circumstances or evidence from which fraudulent intent could be inferred." ${ }^{19}$ The Third, ${ }^{20}$ Sixth, ${ }^{21}$ Ninth, ${ }^{22}$ and Tenth ${ }^{23}$ Circuits have taken similar positions.

\section{The Economic Roots of Section 10(b) and Rule 10b-5 NUISANCE Litigation}

While there are other reasons for a stricter pleading requirement in section $10(\mathrm{~b})$ and rule $10 \mathrm{~b}-5$ litigation, ${ }^{24}$ deterring and dismissing nuisance litigation provides a sound basis for the requirement. ${ }^{25}$ The inherent characteristics of section $10(\mathrm{~b})$ and rule $10 \mathrm{~b}-5$ class-action litigation, as well as the economic incentives facing a professional plaintiff's attorney, ${ }^{28}$ create strong incentives for the initiation of such actions.

18. Stern, 844 F.2d at 1004; Connecticut Nat'l Bank v. Fluor Corp., 808 F.2d 957, 962 (2d Cir. 1987); Ross v. A.H. Robins Co., 607 F.2d 545, 558 (2d Cir. 1979), cert. denied, 446 U.S. 946 (1980); see supra note 9 (Second Circuit construction of rule 9(b)).

19. McGinty v. Beranger Volkswagen, Inc., 633 F.2d 226, 228 (1st Cir. 1980) (citing Cramer v. General Tel. \& Elecs. Corp., 582 F.2d 259, 272-73 (3d Cir. 1978), cert. denied, 439 U.S. 1129 (1979); Felton v. Walston \& Co., 508 F.2d 577, 581-82 (2d Cir. 1974); Walling v. Beverly Enters., 476 F.2d at 397; 5 C. Wright \& A. Miller, Federal. Practice and Procedure: Civil $§ 1297$, at 403-04; $\S 1298$, at $410, \S 1301$, at 426 (1969); 2A J. MoORE, Moore's Federal. Practice I 9.03, at $9-23$ (2d ed. 1979)).

20. Cramer v. General Tel. \& Elecs. Corp., 582 F.2d at 273 ("The second sentence of Rule 9(b) requires only that 'intent, knowledge, and other condition of mind . . . be averred generally.' . . . [G]eneral allegation of the defendants' state of mind meets the minimal requirements of the second sentence of Rule 9(b)." (emphasis in original)).

21. Auslender v. Energy Management Corp., 832 F.2d 354, 356 (6th Gir. 1987) ("[M]alice, intent or knowledge may be averred generally. . . . [T] he allegation of 'recklessness' on the part of [the defendant] is adequate to satisfy the scienter requirement of Rule 10b-5.").

22. Walling v. Beverly Enters., 476 F.2d at 397 ("Nor does Rule 9(b) require any particularity in connection with an averment of intent, knowledge or condition of the mind.").

23. Seattle-First Nat'l Bank v. Carlstedt, 800 F.2d 1008, 1011 (10th Cir. 1986) ("Rule 9(b) does not . . . require any particularity in connection with an averment of intent, knowledge, or condition of mind.' " (quoting Trussell v. United Underwriters, Ltd., 228 F. Supp. 757, 774-75 (D. Colo. 1964))).

24. Courts advance two other justifications for applying the enhanced rule 9 (b) requirement. First, it gives a defendant fair notice of the plaintiff's claim and the grounds upon which it rests, thereby enabling the defendant to prepare a defense. Ross v. A.H. Robins Co., 607 F.2d 545, 557 (2d Cir. 1979), cert. denied, 446 U.S. 946 (1980). Second, it protects the defendant from harm to her reputation or goodwill that might result from unfounded charges of fraud. Decker v. MasseyFerguson, Ltd., 681 F.2d 111, 114 (2d Cir. 1982).

25. Contra Note, supra note 12 , at 1439-40 ("On close analysis . . the policy of deterring and controlling [nuisance] suits fails to justify the dismissal of securities fraud claims under rule 9(b)."); cf. W. CARY \& M. Eisenberg, Cases and Materials on Corporations 888 (5th ed. 1980) (nuisance litigation is "an over-the-hill dragon, puffed into life to frighten the courts away from deciding substantive issues").

26. A professional plaintiff's attorney is a lawyer the bulk of whose practice involves representing plaintiffs on a contingent fee basis. Professional plaintiff's attorneys represent an identifiable subsection of the Bar. In the securities field, they are known as "shareholders lawyers." Borden, The Shareholder Suit Charade, AM. LAw., Dec. 1989, at 67, 68. 


\section{A. Entrepreneurial Litigation}

Section $10(b)$ and rule $10 b-5$ suits usually take the form of class actions where plaintiff's counsel functions in an "entrepreneurial mode." ${ }^{\text {27 }}$ In the typical case, class counsel and the nominal plaintiff act as joint venturers. ${ }^{28}$ Counsel provides the intellectual and pecuniary capital, ${ }^{29}$ while the nominal plaintiff contributes the cause of action. Both venturers expect to earn a return on their investment at some future time. Conflicts of inter$\mathrm{est}^{30}$ and the balance of power within this symbiotic relationship leave members of the plaintiff class with little incentive or ability to monitor class counsel's actions. ${ }^{31}$ Plaintiff's counsel thus controls all major strategic decisions and effectively assumes the role of plaintiff. ${ }^{32}$ As a result, plaintiff's counsel is able to act opportunistically in her own best interests.

One such interest of plaintiff's counsel is to obtain a large and stable income stream. ${ }^{33}$ In this regard, professional plaintiff's counsel views each potential suit as a proffered investment opportunity. As a rational investor, counsel decides whether or not to add the action to her "portfolio"

27. Coffee, The Regulation of Entrepreneurial Litigation: Balancing Fairness and Efficiency in the Large Class Action, 54 U. CHI. L. REv. 877, 882 (1987).

28. Coffee, supra note 10 , at 670 n.2.

29. Class counsel invests intellectual capital in the litigation by providing her services on a contingent fee basis. See Model Rules of Professional Conduct Rule 1.8(j)(2) (1983) (lawyer may "contract with a client for a reasonable contingent fee in a civil case"). Also, class counsel may, and generally does, contribute pecuniary capital by bearing all court costs and expenses of litigation. See id. Rule 1.8(e)(1) ("lawyer may advance court costs and expenses of litigation, the repayment of which may be contingent on the outcome of the matter").

30. Professor Coffee has noted:

It is no secret that substantial conflicts of interest between attorney and client can arise in class action litigation. In the language of economics, this is an "agency cost" problem. All principalagent relationships give rise to agency costs, which consist of (1) the costs of monitoring the agent, (2) the costs the agent incurs to advertise or guarantee his fidelity ("bonding" costs), and (3) the residual costs of opportunistic behavior that it is not cost-efficient to prevent. The classic agency cost problem in class actions involves the "sweetheart" settlement, in which the plaintiff's attorney trades a high fee award for a low recovery.

Coffee, supra note 27 , at 883 .

31. Several factors contribute to this monitoring deficit in class actions. First, plaintiffs are not sufficiently sophisticated to recognize and participate in critical litigation decisions. Second, plaintiffs in securities class actions typically have suffered atomized losses and do not anticipate individual recoveries sufficient to justify the cost of monitoring. Third, no informed market exists for "shares" in a lawsuit. In the absence of such a market, class-action plaintiffs have no means of disciplining counsel by selling out. Finally, because the attorney is the major investor in that she researches, prepares, and finances the entrepreneurial action, class-action plaintiffs become merely a "ticket to ride," and their role is trivialized. Since they have made no real investment of their own, members of the client class possess no leverage and have little incentive to enforce a demand for control of the enterprise. Id. at $884-85$.

32. Coffee, supra note 10 , at 683 .

33. See Coffee, The Unfaithful Champion: The Plaintiff as Monitor in Shareholder Litigation, 48 LAw \& Contemp. Probs. 5, 12 (Summer 1985) (plaintiffs attorney is an entrepreneur "who predictably will act to maximize his expected return and to minimize his risk"). 
based on several investment criteria, including resource constraints, ${ }^{34}$ expected return, ${ }^{35}$ risk aversion, ${ }^{36}$ and ethical considerations.

The portfolio management incentives facing plaintiff's counsel suggest that it is in her best interest to file many suits, with a minimal investment of resources in each suit. ${ }^{37}$ In seeking to maximize a stable, contingent feebased revenue stream from her investments, plaintiff's counsel will seek a diverse portfolio of suits in order to minimize her dependence on the outcome of any one action. A professional plaintiff's counsel can maintain a "diverse" portfolio by filing numerous actions. ${ }^{38}$ Further, she will seek to minimize her "position" in any given suit to guard against losses due to adverse judgments. For example, an attorney can minimize her research investment in each case by litigating in a limited area of the law, since litigation in any area of law requires some specialized knowledge.

In sum, in the contingent fee context of the typical class action, strong entrepreneurial incentives influence plaintiff's counsel to initiate a maximum number of suits requiring a minimum investment of resources in each action. These incentives are reinforced by the "litigation differential" in section $10(\mathrm{~b})$ and rule $10 \mathrm{~b}-5$ class actions.

\section{B. The Litigation Differential}

The "litigation differential" 39 in corporate litigation expresses the fact that it is often less expensive for a plaintiff to initiate and maintain an

34. A plaintiff's attorney will refuse a proffered investment opportunity if she is unable to devote sufficient resources to pursue it effectively. For example, her firm may simply lack the physical or financial capacity to take on the new matter, or she may be unwilling to expend the extra hours necessary to initiate the action if her support staff already is overextended.

35. Plaintiff's counsel will not pursue a claim when she does not expect to receive a fee award (from the court or the defendant) large enough to pay a competitive return on her investment in litigation expenses and to cover her opportunity costs. Coffee, supra note 10, at 695 . Counsel calculates her expected fee based on factors such as the potential size of the fee, the probability of receiving that fee, and the point in time she expects to receive the fee.

36. A risk-neutral plaintiff's attorney would be indifferent between pursuing a case having a $10 \%$ chance of generating $\$ 10,000,000$ in fees and one having a $50 \%$ probability of a $\$ 2,000,000$ payoff. In practice, an attorney is constrained by custom, social convention and legal ethics from making "covariant" litigation investments, and she is unable to achieve optimal portfolio diversification. Id. at $705 \& \mathrm{n} .100$. As a result of suboptimal portfolio diversification and other practical considerations such as meeting the firm payroll and paying monthly overhead costs, plaintiff's counsel may not behave like a risk-neutral investor and may, on balance, prefer the $50 \%$ chance of a $\$ 2,000,000$ return in the example above. See Coffee, supra note 33 , at 12 (plaintiff's attorney predictably will act to minimize her risk).

37. Coffee, supra note 33 , at 22-23.

38. A plaintiff's attorney can diversify the risk inherent in her portfolio of actions in two ways: by making co-variant litigation investments or by filing as many actions as possible, given her resource constraints. In practice, a plaintiff's attorney cannot make co-variant litigation investments. Coffee, supra note 10, at 705 \& n.100. Thus, her only option in diversifying her portfolio is to file as many suits as her resources will allow.

39. Professor Geoffrey Miller coined the term "litigation differential" in his article An Economic Analysis of Rule 68, 15 J. LEgal STUD. 93, 99 (1986). Professor Miller defined the litigation differential at any given time as "the sum of defendant's attorneys' fees, plaintiff's attorneys' fees, defendant's costs, and plaintiff's costs. These are the 'direct costs' of going to trial rather than settling." Id. (footnote omitted). 
action than it is for a corporation to defend the action. More specifically, the litigation differential is the difference between the cost to the plaintiff of initiating and maintaining a suit ${ }^{\mathbf{4 0}}$ and the expected cost to the defendant of preparing and trying the case to judgment. ${ }^{41}$ It is a structural phenomenon which exists independently of the merits of the plaintiff's claim. ${ }^{42}$

At any point in time after a plaintiff has initiated an action, the defendant has two options: litigate the matter to judgment or pursue a strategy aimed at settling the dispute. ${ }^{43}$ In deciding whether to fight or settle, corporate decisionmakers tend to give more weight to the relative expense of the two options than to the merits of the suit. ${ }^{44}$ The rational corporate defendant will prefer settling a claim, irrespective of its merits, as long as the cost of settlement is less than the expected cost of litigating to judgment. ${ }^{45}$ Thus, when a litigation differential exists, settlement at any amount between plaintiff's costs of initiating and maintaining the action to date and defendant's prospective costs of litigating the action to judgment can be a profit maximizing outcome for both parties. ${ }^{46}$ In cases where known facts indicate that a litigation differential exists, a class-action plaintiff's counsel may thus appropriate some portion of the differential merely by filing suit, irrespective of the merits of her case. Plaintiff's counsel believes that the corporate defendant will prefer to settle for some

For purposes of this Note, "litigation differential" will mean the difference between plaintiffs sunk attorney's fees and costs and defendant's sunk and expected future attorneys' fees and costs. The litigation differential as employed in this Note attempts to model the pecuniary values evaluated by each party at any point in time in deciding whether to settle the dispute or continue litigating to judgment. See infra notes 43-47 and accompanying text.

40. These costs include court filing fees and other disbursements as well as the opportunity cost of the attorneys' time and any sanctions generated by their actions.

41. Sep also Rosenberg \& Shavell, supra note 10 (describing model of litigation process that incorporates litigation differential); Coffee, supra note 27 (discussing effect of litigation differential on class actions).

42. For a discussion of the causes of the litigation differential in $\S 10(\mathrm{~b})$ and rule $10 \mathrm{~b}-5$ actions, see infra notes $48-53$ and accompanying text.

43. The fact that a plaintiff, merely by filing suit, can force defendant to expend the substantial resources required to prepare a defense or to settle, independent of the merits of the suit, has also been called the tin terrorem settlement value of a complaint. Blue Chip Stamps v. Manor Drug Stores, 421 U.S. 723, 741 (1975).

44. The "expense" of each option includes both quantifiable costs (such as attorneys' fees and court expenses) and non-quantifiable costs (such as executives' time, lost reputational capital, and decreased certainty). For a more detailed description of the components of these costs, see Coffee, supra note 27, at 891 \& nn.33-34; Coffee, supra note 10, at 701-02 \& nn.93-94; Coffee, supra note 33 , at $17-18$.

45. At least one experienced Federal judge maintains that candidates for settlement are readily identifiable:

They are the cases in which the amount involved is small in relation to the anticipated costs of litigation, or in which relief other than the payment of money is the plaintiff's principal objective and it is less painful for the defendant to give that relief than to bear the expense of further litigation.

Tone, The Role of the Judge in the Settlement Process, in SEMinars for Newly APpointed United States District Judges 57, 62 (1975).

46. The plaintiff has obtained a settlement in excess of her sunk costs. The defendant has terminated a problem at a lower cost and more quickly than through litigation to judgment. 
amount in excess of its costs and that she and her clients may profit from the litigation differential. ${ }^{47}$

The litigation differential is marked in section 10(b) actions. Defendants typically face substantially higher costs of engaging in section $10(\mathrm{~b})$ and rule $10 \mathrm{~b}-5$ litigation than do plaintiffs. ${ }^{48}$ The litigation differential in section 10(b) lawsuits is also peculiarly appropriable for several reasons. First, both plaintiff's and defendant's counsel are acutely aware of the existence of the litigation differential in these actions and can gauge its size. ${ }^{48}$ Second, the defendants in section $10(\mathrm{~b})$ actions usually are corporations and their managers. The defendants are subject to the "tyranny of the quarterly report," and their decisions concerning whether to litigate are commonly based on cost/benefit analyses in which the merits of any lawsuit are but one factor. If it is cheaper to settle than to fight, they will settle. $^{\mathrm{so}}$ Third, securities lawsuit defendants generally are not repeat "players" in the securities litigation "game." As As infrequent litigants, they have little incentive to deviate from the least expensive option in any one action by employing strategic tactics designed to enhance their reputa-

47. Plaintiff's attorneys who are known for capitalizing on the litigation differential have received the "colorful" appellation of "pilgrims" from their associates at the bar. These "early settlers" are a specific identifiable subset of the plaintiff's bar. Coffee, supra note 33, at 44 \& n.122; Borden, supra note 26 , at 68 .

48. See Coffee, supra note 10, at $697 \mathrm{n} .79$ ("The conventional wisdom is that litigation costs lin class and derivative actions] tend to be lower for plaintiffs than defendants.").

According to data compiled by The Wyatt Company, an insurance consulting firm, the average cost of defending a claim made against corporate directors was $\$ 461,000$ in 1984 . It is highly doubtful that plaintiffs spend (or could spend) even a substantial fraction of this amount on a per action basis.

Id. at 702 n.94 (citing Schatz, Focus on Corporate Boards: Directors Feel the Legal Heat, N.Y. Times, Dec. 15, 1985, at F13, col. 2).

The amended complaint in Stern v. Leucadia Nat'l Corp., 844 F.2d 997 (2d Cir.), cert. dented, 109 S. Ct. 137 (1988), provides a concrete example of the litigation differential. The district court awarded Leucadia $\$ 7500$ for the costs incurred in making its second motion to dismiss. Stern, 844 F.2d at 1003. The amendments to the complaint consisted of citations to several news articles speculating about Leucadia's intentions in the transaction, all of which would have been available from one or more on-line news databases such as Nexis, Dow Jones New Service, or Investext. It is highly unlikely that plaintiff's counsel invested half as much time and money researching and preparing the amended complaint as defense counsel billed Leucadia for responding to it.

49. The securities bar has commented on the phenomenon extensively. See, e.g., Rosenberg \& Shavell, supra note 10; Coffee, supra note 27. Moreover, as sophisticated players in this game, the members of this bar are well informed concerning both their own costs and those of their opponents.

50. Corporate managers are under continuing pressure to operate their enterprises as profitably as possible. The market price of a corporation's stock is influenced strongly by its reported earnings. Managers are thus under greater pressure to keep earnings high from month to month rather than over a long term. This pressure causes managers to view the short-run costs of settling versus litigating in dollar terms, rather than the merits of the suit, as the criterion to be used in making the fight/ settle decision. See Nazario, supra note 10, at B1, col. 6, B6, col. 4 (most companies choose to settle cases that lack merit but would cost more to defend than to settle; senior vice president of Pic ' $N$ ' Save Corp. says company may adopt policy of fighting such nuisance suits if there is evidence that doing so would lessen overall legal costs without hurting company's reputation in community or its sales).

51. The results of the most complete study of the incidence of litigation against corporations indicate that an average public corporation faces derivative or securities class-action litigation only once every 17.6 years. Jones, An Empirical Examination of the Incidence of Shareholder Derivatize and Class Action Law'suits, 1971-1978, 60 B.U.L. REv. 306, 316 (1980). 
tion for toughness and deter future nuisance suit plaintiffs. ${ }^{52}$ Fourth, settlement offers something that corporate managers value highly: certainty. Managers are willing to pay a premium for this certainty because it removes a problem from their desks by reducing an unknown to a known. Settlement also removes a contingency from their companies' financial statements that has costs independent of the litigation itself..$^{63}$

The existence and the appropriability of the litigation differential in section $10(\mathrm{~b})$ and rule $10 \mathrm{~b}-5$ actions, combined with the entrepreneurial incentives influencing plaintiff's counsel, encourage her to file as many section $10(\mathrm{~b})$ and rule $10 \mathrm{~b}-5$ suits as possible. ${ }^{54}$ Relative indifference to the merits and an interest in making a minimal investment of resources in each suit thus produce nuisance litigation. ${ }^{\mathrm{ss}}$

\section{Policy Goals Governing Antidotes to Section 10(b) ANd Rule 10b-5 Nuisance Litigation}

In the short run, the quantity of Federal judicial resources is fixed. In light of this fact, a critical goal of the Federal legal system is to make efficient use of the existing judicial resources by conserving, to the extent

52. Defendants who appear frequently in the securities litigation arena have incentives to focus on the long-term effects of each action and invest in reputational capital by resisting frivolous actions even when it would be cheaper to settle each individual case. By earning and maintaining reputations as "tough, hard-nosed litigators who will not settle weak cases," repeat players such as accounting firms and insurance companies seek to deter future nuisance actions. Coffee, supra note 33, at 14; see Nazario, supra note 10, at B6, col. 4 (senior counsel for Stop \& Shop Cos. believes "[i]n the long run, Standard Brands' policy [of fighting rather than settling all nuisance suits] 'will probably dissuade people from suing them' because plaintiffs' attorneys 'won't think they are an easy mark'. ....").

Stern v. Leucadia Nat'l Corp., 844 F.2d 997 (2d Cir.), cert. denied, 109 S. Ct. 137 (1988), discussed supra note 48 , may provide a concrete example of this phenomenon. Leucadia is in the business of participating in corporate change of control transactions. As a result, Leucadia is a repeat securities litigant and therefore had strong incentives to litigate rather than settle Stern's claim in the hope of deterring future strike suits. In the end, Leucadia's tenacity was rewarded; the Second Circuit affirmed the dismissal of Stern's complaint on a rule 9(b) motion. Id. at 1006.

53. It is also important that corporate managers pay settlements with "other people's money." Plaintiff's lore has it that it is easier to obtain a settlement from the managers of a publicly held corporation, where the stockholders or the customers ultimately take the "hit," than it is to settle with a partnership, where the principals must often pay the settlement personally. Corporate managers also may not feel that their personal reputations have been impugned or need defending, so they may not be as disposed to fight, either as a matter of principle or on personal grounds, as partners are.

54. See supra notes $37-38$ and accompanying text.

55. One commentator has written:

During the dealmaking boom of the $1980 \mathrm{~s}$. . . a particular mutation of the shareholder class action has flourished-the automatic complaint. As Chancellor Allen lectured at the Champion settlement hearing in August, "Every time there is an announced offer, there is an industry of class action lawyers who will file a suit, even when a board is fully independent and fully functioning to meet its obligations." ...

Joseph Rosenthal, a leading local plaintiffs [sic] counsel . . . disputes this notion. "That may be the perception,... . [b]ut my view is that few deals result in serious litigation." And, he asserts, plaintiffs [sic] counsel drop "the bulk of the cases" after determining that shareholders have been treated fairly.

That only confirms the point.

Borden, supra note 26 , at 68 (emphasis supplied) (discussing securities fraud actions in Delaware courts). Only one in 10 suits has merit, but which one is not known when they are filed. Id. at 69 (quoting Charles Richards, Jr.). 
possible, the resources expended on any one action. ${ }^{56}$ This policy maxim dictates that legal institutions governing litigation in general, and section 10 (b) and rule 10b-5 litigation in particular, ${ }^{57}$ should discourage and dismiss summarily non-meritorious suits, so long as this can be accomplished without unduly impeding meritorious suits. Affording judges a means of dealing summarily with nuisance litigation will reduce the amount of judicial resources expended on dispatching non-meritorious claims, thereby allowing courts to expend their limited resources on resolving meritorious disputes.

Antidotes to nuisance litigation will also help preserve the integrity and legitimacy of the judicial process. The securities nuisance litigationsettlement cycle constitutes abuse of process by the plaintiff's bar at the expense of the target defendants' shareholders and customers. To fund the settlement of non-meritorious suits, defendants may need to reduce or eliminate dividends to their shareholders, take an earnings "hit," and/or raise product prices and pass the cost on to the consuming public. In addition, this misappropriation receives a legal imprimatur that ultimately undermines public confidence in the legal system. ${ }^{58} \mathrm{~A}$ procedural device that reduces or eliminates plaintiff's counsel's economic incentives to perpetrate this abuse will serve fundamental policy interests.

However, any solution that minimizes waste of judicial resources and extortionate abuse of process must not frustrate meritorious suits unduly. Meritorious lawsuits could be inappropriately deterred or dismissed under procedural rules that place unreasonable demands on a plaintiff's knowledge or ability to commit resources. Such overly restrictive procedural rules would thus diminish the effectiveness of the substantive securities law in deterring and punishing, and remedying the consequences of, fraud and other proscribed behavior. ${ }^{59}$ In addition, overly restrictive pleading

56. Increased efficiency provides one way to reduce the crowded dockets facing the Federal courts without an added expenditure of taxpayer dollars on additional judicial resources. Increased judicial efficiency also increases public confidence in the legal system. The celebrated person in the street continues to believe, and not without reason, that justice delayed is justice denied.

57. In 1988 , class actions accounted for $0.4 \%$ of the Federal courts' total workload, and securities class actions accounted for $14.6 \%$ of all the class actions filed. 1989 CLASS ACTion REP. 7 (citing Report of the Administrative Office of the United States Courts for fiscal year 1988). However, "class and derivative actions are typically complex and time consuming, proceed at a glacial pace, and tend to proliferate a variety of collateral issues." Coffee, Rescuing the Private Attorney General: Why the Model of the Lawyer as Bounty Hunter Is Not Working, 42 MD. L. REv. 215, 228 (1983). In addition, "[s]ecurities class actions tend to involve more judicial time than most cases." Summit \& Leber, Posing the Question, 'Whodunwhat?': Using Rule $9(b)$ to Challenge Securities-Fraud Actions, Nat'l L.J., Dec. 24, 1984, at 15, col. 1.

58. To the extent the public perceives the ability of certain individuals to obtain undeserved returns through the use of the courts, it should undermine their confidence in the legal system as a whole.

59. Enforcement of the securities laws by the Securities and Exchange Commission and "private attorneys general" serves the dual purposes of compensating persons injured by violations of those laws and deterring future wrongdoing. Lerach, Securities Class Actions and Derizative Litigations Intolving Public Companies: A Plainitffs Perstective, 491 PLI-CORP. 7, 63-64 (1985) (citing Mills v. Electric Auto-Lite Co., 396 U.S. 375, 396-97 (1970); J.I. Case Co. v. Borak, 377 U.S. 426, 432 
requirements would themselves undermine public confidence in the legal system. $^{60}$

\section{Analysis and a Proposal}

This Part first analyzes the opposing judicial views with respect to the use of rule $9(\mathrm{~b})$ to dismiss and to deter section $10(\mathrm{~b})$ and rule $10 \mathrm{~b}-5$ nuisance litigation in light of the competing policy goals noted above. It then suggests a new procedure with which courts could deter and dismiss summarily nuisance actions while not impeding meritorious suits.

\section{A. Analysis}

The Second Circuit interpretation of rule 9(b), requiring plaintiffs to "specifically plead those events which they assert give rise to a strong inference that the defendants had [scienter]," ${ }^{\prime 1}$ has three advantages over the contrary view: ${ }^{62}$ it deters the commencement of nuisance litigation more effectively; it provides a more effective tool for dismissing nuisance suits that are initiated; and it makes more efficient use of judicial resources. However, the stricter pleading requirement may result in undue deterrence and dismissal of meritorious claims.

The Second Circuit position operates directly on the economic incentives to initiate nuisance litigation by narrowing the litigation differential substantially in two ways. First, it reduces the cost of litigating a nonmeritorious claim to judgment. Afforded the opportunity to dispose of lawsuits at the pleading stage at a relatively modest cost, defendants can be expected to seek vindication through the courts rather than agreeing to expensive, unjust settlements that appropriate money from their shareholders and customers. ${ }^{63}$ Second, the Second Circuit interpretation of rule 9(b) raises the cost to plaintiff's counsel of commencing and maintaining a suit by increasing the level of factual and legal inquiry necessary to meet the stricter scienter pleading requirement. ${ }^{64}$ The Second Circuit rule thus reduces plaintiff's counsel's perceived litigation differential, decreasing the chance that filing a suit will afford her a sufficient return on her anticipated investment in the nuisance action.

(1964)). To the extent that procedural rules interfere with or prevent this enforcement, they limit its effectiveness as a remedy and deterrent.

60. Public confidence in the legal system is undermined when defendants who "did it" are "let off" on procedural technicalities.

61. Ross v. A.H. Robins Co., 607 F.2d 545, 558 (2d Cir. 1979), cert. denied, 446 U.S. 946 (1980).

62. Sie supra notes 19-23 and accompanying text.

63. It could be argued that the Second Circuit standard results in an increase in motion practice and thus requires more judicial resources than the majority position. This argument ignores the fact that hearing motions requires far less judicial time and energy than trying cases.

64. This extra research has an additional and often ignored benefit. During the course of this additional inquiry, a well-meaning but mistaken plaintiff's counsel may uncover facts that will lead her not to initiate the action. 
Conversely, the position of the other circuits invites nuisance litigation. Proving scienter is a difficult exercise, requiring extensive discovery in which plaintiff's counsel can impose significant costs on the defendant at a relatively low cost to herself. ${ }^{\text {es }}$ Accordingly, introducing a substantive scienter requirement ${ }^{68}$ increases the amount of resources a defendant expects to expend in complying with discovery requests. Without a corresponding procedural requirement that reduces the probability that the defendant will have to expend these resources, the litigation differential increases. The other circuits' position increases the differential further because their scienter pleading requirement is more easily met. Merely alleging scienter "on information and belief" is much less expensive than expending the resources necessary to uncover, analyze, organize, and verbalize circumstances that "give rise to a strong inference that the defendants had [scienter]." ${ }^{187}$ In sum, introducing the substantive scienter requirement without also requiring an enhanced pleading standard under rule $9(\mathrm{~b})$ increases the litigation differential and the incentive to initiate nuisance litigation. This result runs counter to the policy of conserving judicial resources as well as the Supreme Court's intention to deter nuisance securities litigation by implementing the substantive scienter requirement. ${ }^{68}$

Finally, the other circuits' less rigorous pleading standard reduces rule 9(b)'s effectiveness as a tool for dismissing nuisance litigation. Plaintiffs can more easily meet the lower pleading standard, regardless of the merits of their claims. It therefore allows questionable actions that would be dismissed in the Second Circuit to survive the pleading stage. ${ }^{69}$

One result of this ineffectiveness is that the other circuit courts expend many more judicial resources in disposing of nuisance lawsuits. Absent an enhanced pleading requirement, more nuisance suits survive the pleading

65. Professor Coffee has noted:

[T]he financial burdens associated with discovery fall more heavily on the defendants. Without much time or effort, the experienced plaintiffs' attorney can prepare a voluminous list of interrogatories and demand production of crates of documents. Responding to these requests takes more time; files must be searched, answers drafted, and objections made. Witnesses must also be prepared for deposition, and this can involve a rehearsal process that exceeds the length of the actual deposition.

Coffee, supra note 33, at 17 . Discovery regarding scienter is especially difficult, expensive, and time consuming because it necessarily involves inquiry into persons' states of mind at various points in time.

66. Ernst \& Ernst v. Hochfelder, 425 U.S. 185, 192 n.7, 193 (1976).

67. Ross v. A.H. Robins Co., 607 F.2d 545, 558 (2d Cir. 1979), cert. denied, 446 U.S. 946 (1980).

68. See supra note 15 and accompanying text.

69. Compare Denny v. Carey, 78 F.R.D. 370 (E.D. Pa. 1978) (complaint not challenged on rule 9(b) grounds) with Denny v. Barber, 576 F.2d 465 (2d Cir. 1978) (affirming dismissal with prejudice of complaint virtually identical to that filed in Carey for failure to allege fraud with particularity required by rule 9(b)); compare Deutsch v. Flannery, 823 F.2d 1361, 1363 (9th Cir. 1987) (reversing district court's dismissal of two of plaintiffs' $\S 10(\mathrm{~b})$ and rule $10 \mathrm{~b}-5$ claims; complaint's statement of said claims sufficiently particular to satisfy rule 9(b)) with Deutsch v. Flannery, 597 F. Supp. 917 (S.D.N.Y. 1984) (complaint dismissed without prejudice for failure to allege facts indicating scienter with particularity required by rule $9(\mathrm{~b}))$. 
stage and continue to absorb judicial resources with discovery issues and dispositive motions as they proceed toward trial or settlement.

The strongest argument against the Second Circuit interpretation of rule 9 (b) is that its benefits may come at the price of an unacceptably high risk of deterrence and premature dismissal of meritorious claims. ${ }^{70}$ Plaintiffs in the Second Circuit allegedly are deterred from making meritorious claims because, although they may satisfy the rule 9 (b) standard with respect to the other elements of a section $10(\mathrm{~b})$ and rule $10 \mathrm{~b}-5$ cause of action, they are unable to plead scienter with sufficient particularity without some discovery, ${ }^{71}$ which they would be denied. Meritorious suits are therefore dismissed prematurely or never initiated because plaintiffs are unable to plead essential facts that are peculiarly within defendants' ken and control. The risk is "that the defendant has so effectively concealed [its] wrongdoing that the plaintiff can unearth it only with discovery. To insist on details as a prerequisite to discovery is putting the cart before the horse."72

In summary, the Second Circuit's stricter interpretation of rule 9(b) with respect to pleading scienter may be preferable to the position of the other circuits because it offers a superior method of handling nuisance litigation, and because it remains more consistent with the policy goals underlying the introduction of a substantive scienter requirement. However, this cure is potentially worse than the disease if it deters or dismisses meritorious claims.

\section{B. Proposal}

The above analysis suggests that a slight modification of the implementation of the Second Circuit scienter pleading standard would remedy its deficiencies while retaining virtually all of the advantages that make it the preferred interpretation of rule 9(b). The proposed modification would allow plaintiff limited discovery ${ }^{73}$ for the sole purpose of enabling her to attempt to meet the elevated Second Circuit scienter pleading requirement. Such discovery would be permitted only if the plaintiff 1) has met all other, non-scienter pleading standards; 2 ) has conducted a reasonable in-

70. Note, supra note 12 , at $1435,1438$.

71. Plaintiffs may be unable to specify the circumstances that lead to an inference of scienter for two interrelated reasons. First, $\$ 10(\mathrm{~b})$ plaintiffs generally have had contact with the defendani only indirectly and through impersonal market channels when they acquired their securities. Plaintiffs therefore have little firsthand knowledge about the particulars of potentially fraudulent transactions. Blue Chip Stamps v. Manor Drug Stores, 421 U.S. 723, 745 (1975) ("In today's universe of transactions governed by the 1934 Act, privity of dealing or even personal contact between potential defendant and potential plaintiff is the exception and not the rule."); Note, supra note 12, at 1436. Second, due to the "shroud of secrecy that surrounds most current capital-market transactions," plaintiffs encounter practical difficulties in ascertaining the particulars of potentially fraudulent transactions. Id. at $1438-39$.

72. Marcus, supra note 12 , at 468 .

73. Spe infra note 83. 
quiry consistent with rule $11^{74}$ in an attempt to meet the scienter pleading requirement; and 3) has been unable to meet the scienter pleading standard because the necessary information is peculiarly within the knowledge of defendant. ${ }^{75}$ If plaintiff cannot meet the enhanced scienter pleading requirement after this limited discovery, the action should be dismissed with prejudice. $^{76}$

\section{Procedure}

The proposed limited discovery procedure ("LDP") would be triggered by defendant's rule 9 (b) motion to dismiss in response to a complaint. ${ }^{77}$ Under the LDP, the plaintiff would incorporate a request for limited discovery into the response she normally would file in opposition to defendant's rule 9(b) motion. Plaintiff's LDP request would have two components: 1) an affidavit regarding the extent of her research as to defendant's scienter; ${ }^{78}$ and 2) a proposed discovery request. ${ }^{79}$

Under the LDP, the decision as to whether to allow limited discovery would be made during the hearing on defendant's rule 9(b) motion. If the plaintiff's complaint does not meet all non-scienter pleading requirements under rule 9(b), the suit would be dismissed with leave to replead and without prejudice. ${ }^{80}$ If plaintiff's complaint meets the non-scienter pleading requirements and meets the enhanced scienter pleading requirement

74. Rule 11 provides, in pertinent part:

The signature of an attorney or party [on a pleading, motion, or other paper] constitutes a certificate by the signer that . . to the best of the signer's knowledge, information, and belief formed after a reasonable inquiry it is well grounded in fact and is warranted by existing law or a good faith argument for the extension, modification, or reversal of existing law, and that it is not interposed for any improper purpose, such as to harass or to cause unnecessary delay or needless increase in the cost of litigation.

FED. R. Crv. P. 11 (emphasis supplied).

75. See infra notes 80-82 and accompanying text.

76. See infra note 86 .

77. Presumably the LDP would take place prior to determination of the class certification question. Treating the question of class certification prior to the LDP would be inconsistent with the goals of the LDP because it would delay the dismissal of non-meritorious suits as well as increase the litigation differential by forcing the defendant to expend the resources necessary to oppose class certification.

78. The affidavit would take the form of a statement wherein plaintiff's counsel avers that, after reasonable inquiry, she has been unable to discover sufficient circumstances to create an inference of scienter because, to the best of her knowledge, information and belief, those circumstances are within the exclusive control of the defendant. Counsel would attach a list of the sources she has consulted in her inquiry as an exhibit to this affidavit.

79. The LDP proposed discovery request would be a list of the documents plaintiff wishes to examine, the persons she would like to depose, and the interrogatories she wants answered in her effort to meet the enhanced scienter pleading standard. Because of the limited scope of the LDP, the discovery request would contain an explanation, on an element by element basis, of the reason(s) for plaintiff's belief that each element of the request is reasonably calculated to lead to the discovery of circumstances that would support an inference of scienter.

80. This procedure is effectively authorized by FED. R. CIv. P. 15(a), which authorizes a party to amend its pleading "once as a matter of course at any time before a responsive pleading is served . . ." Id. It would be highly unusual for a defendant to file an answer to the original, unamended cornplaint after an order dismissing the case but granting plaintiff leave to replead. 
then defendant's rule 9 (b) motion would be denied. If plaintiff has not met the scienter pleading standard, and her LDP request meets the other two criteria described above, then the judge would convene a discovery conference pursuant to rule $26(\mathrm{f})^{81}$ as a part of the rule $9(\mathrm{~b})$ hearing. At the rule $26(f)$ conference, the judicial officer ${ }^{82}$ would determine the scope of the limited discovery ${ }^{83}$ to be granted plaintiff. ${ }^{84}$ Plaintiff would be afforded leave to amend her complaint within a specified period, if so advised, to reflect any new information uncovered during the limited discovery allowed.

If the plaintiff does not replead after the limited discovery, her complaint would be dismissed with prejudice. ${ }^{85}$ If, however, the plaintiff amends the complaint, the defendant could renew its rule 9(b) motion, precipitating another hearing, or allow the action to proceed. If the defendant renews its rule 9(b) motion, a second rule 9(b) hearing would be convened to determine whether the amended complaint meets the enhanced scienter pleading standard. If she has, pre-trial proceedings would continue; if she has not, her complaint would be dismissed with prejudice. $^{88}$

81. FED. R. Crv. P. 26(f) (timing, scope, and procedure of discovery conference).

82. In practice, it might be mare appropriate for a magistrate who has some familiarity with the securities area to preside over the rule $26(f)$ conference. The magistrate, because of her specialized knowledge, would more likely be able to fashion a fair "scope" order than the trial judge.

83. The "limited" discovery suggested by this Note differs from the "limited" discovery proposed by another commentator. See, Note, supra note 12, at 1443. The "limited" discovery advocated by this other commentator takes place after a plaintiff has satisfied the rule $9(\mathrm{~b})$ pleading standard, and it is "limited" only in the sense that the judge takes an active role in "managing" the discovery to ensure that plaintiff's discovery requests are not overly broad and/or burdensome by, among other things, limiting the discovery to particular issues. The scope of the discovery, however, remains unlimited. Plaintiff's goal is to discover facts sufficient to prove by a preponderance of the evidence that the defendant(s) acted with scienter. Herman \& MacLean v. Huddleston, 459 U.S. 375, 388-89, 390 (1983) (preponderance of evidence standard is appropriate standard of proof in private damages actions under $\S 10(\mathrm{~b})$ and rule $10 \mathrm{~b}-5$ ). Further, discovery may proceed on all issues simultaneously.

In contrast, the limited discovery under the proposed LDP would take place before the complaint meets the rule 9(b) standard. More importantly, it is "limited" in scope. Plaintiff's goal under the LDP would be to discover facts sufficient to give rise to a strong inference that the defendant(s) acted with scienter. The extent of discovery reasonably necessary to meet this limited goal would be far less than under "managed" discovery because the level of proof the plaintiff seeks would be so much lower. Further, the narrow scope inherent in the LDP would limit the costs plaintiffs can impose on defendants through discovery. Thus, the litigation differential would be significantly smaller under the LDP than under the post-certification, full scope, managed discovery proposed by the other commentator.

84. Presumably, the judicial officer would grant or modify the proposed discovery request contained in plaintifr's response to defendant's rule 9 (b) motion.

85. "Where . . . the order of dismissal without prejudice is subject to certain conditions that plaintiff]s] must comply with, the court may render a judgment of dismissal with prejudice upon plaintiff's failure to comply with the conditions." $5 \mathrm{~J}$. MOORE \& J. LuCAS, MOORE's Federal PRACTICE If 41.05[2], at 41-66 (2d ed. 1990). These conditions can include leave to replead within a specified time period. For an example of this theory in action, see Kimmel v. Labenski, [1987-1988 Transfer Binder] Fed. Sec. L. Rep. (CCH) II 93,651, at 97,991 (S.D.N.Y. 1988) (Haight, J.) ("I grant plaintiff leave to replead with respect to all defendants. If so advised, plaintiff may file and serve an amended complaint within sixty (60) days of the date of this order, failing whi[c]h the fraud claims will be dismissed with prejudice.").

86. Where plaintiffs have had an opportunity to amend their complaint with notice of its deficiencies and have failed to correct them, dismissal with prejudice is proper. Luce v. Edelstein, 802 F.2d 


\section{Scope and Methods of Discovery}

Both the scope and methods of the discovery to be allowed plaintiff under the LDP must be left largely to the discretion of the judicial officer. In deciding how much discovery will be allowed and what methods will be available to the plaintiff, the decisionmaker ought to apply a standard which both minimizes the defendant's cost of compliance and allows the plaintiff to discover the information needed to meet the enhanced scienter pleading standard. Such discovery should be limited to documents, depositions, and interrogatories reasonably calculated to lead to discovery of circumstances giving rise to an inference of scienter. This standard is consistent with the standard applicable to general discovery set forth in rule $26(b)(1){ }^{87}$ The decisionmaker must have discretion to afford or to deny plaintiff the use of any or all of the discovery methods available in general discovery practice ${ }^{88}$ in order to tailor the limited discovery to individual fact situations. For example, in litigation concerning a transaction, the plaintiff may need to depose one or more of the parties to the transaction in her attempt to meet the enhanced scienter pleading requirement, while in an action against an accounting firm, discovery of the accountants' workpapers may be sufficient. ${ }^{89}$

Authority for implementing the LDP lies in rule 26(f), which authorizes a court to convene a discovery conference "[a]t any time after commencement of an action" and requires the court to "enter an order tentatively identifying the issues for discovery purposes, establishing a plan and schedule for discovery, setting limitations on discovery, if any; and determining such other matters, including the allocation of expenses, as are necessary for the proper management of discovery in the action." Further, the order "may be altered or amended whenever justice so re-

49, 56 (2d Cir. 1986); Armstrong v. McAlpin, 699 F.2d 79, 93-94 (2d Cir. 1983); Decker v. MasseyFerguson, 681 F.2d 111, 115 (2d Cir. 1982); Denny v. Barber, 576 F.2d 465, 470-71 (2d Cir. 1978). The plaintiff will have had two opportunities to demonstrate a basis for the serious charges made against the defendants. Having failed to meet the requirements of rule $9(\mathrm{~b})$ even after limited discovery granted under the proposed LDP, plaintiff should not be entitled to a third bite at the apple.

Furthermore, fairness, efficiency, and common sense all dictate that plaintiff's complaint be dismissed with prejudice at this juncture. Plaintiff has already had discovery and cannot meet the rule 9(b) standard. Merely granting her an extension and allowing a repleading is thus highly unlikely to lead to uncovering new facts sufficient to give rise to an inference that defendants acted with scienter. Thus, dismissal at this time is not unfair to plaintiff. The defendants have been subjected to discovery and forced to respond to an amended complaint. Fairness dictates that the defendants are entitled to final judgment on the matter. Dismissal with prejudice is efficient because it acts as res judicata to bar another action by this plaintiff on the claim so dismissed, and thus prevents re-litigation of nonmeritorious claims as well as harassment of the defendant. Finally, common sense indicates that once a plaintiff has had discovery, merely giving her more time to re-research and replead her complaint has little chance of producing any significant new information.

87. FED. R. Crv. P. 26(b)(1).

88. Plaintiff may thus request the use of depositions (FED. R. Crv. P. 30), depositions upon written questions (FED. R. Crv. P. 31), interrogatories (FED. R. Crv. P. 33), document production (FED. R. CIV. P. 34), and requests for admission (FED. R. Civ. P. 36).

89. See In re Frank B. Hall \& Co. Secs. Litigation, 693 F. Supp. 1460 (S.D.N.Y. 1988).

90. FED. R. Crv. P. 26(f) (emphasis supplied). 
quires."91 Under the LDP, the court would convene a discovery conference during the hearing on defendant's rule 9(b) motion and would enter an oral or written order: 1) identifying the issue for discovery purposes as the elucidation of the existence of circumstances leading to an inference of scienter; 2) setting a timetable for discovery on this issue; and 3) narrowing the scope of the discovery in accordance with the limited issue.

\section{Impact}

The proposed LDP would sacrifice a minimal amount of nuisance suit deterrence and dismissal force relative to the current Second Circuit practice because it would result in a relatively small increase in the litigation differential. This marginal increase would consist of the cost to the defendant of the limited discovery that may be made available to plaintiffs, ${ }^{92}$ less plaintiff's counsel's cost of pursuing that discovery. However, this cost increment should be minimal enough for the defendant to incur and remain in the lawsuit seeking dismissal, rather than opting for a nuisance value settlement. ${ }^{\text {.3 }}$

Further, the LDP should reduce the undue deterrence or dismissal flaw inherent in the Second Circuit standard. Plaintiffs able to meet the nonscienter pleading standards and willing to conduct a good faith search for the "circumstances from which scienter may be inferred" would be given a fair opportunity to discover the facts necessary to meet the enhanced pleading requirement. Accordingly, they would not be deterred from initiating meritorious lawsuits, nor would such lawsuits be dismissed on rule 9(b) motions.

While the LDP would lower a nuisance suit's chance of dismissal relative to the Second Circuit's interpretation of rule 9(b), it would represent a significant improvement on the other circuits' interpretation because it would provide the advantages of the stricter scienter pleading standard.94 At the same time, the LDP's great benefit would be that the plaintiffs who take advantage of it should be plaintiffs with valid claims whose suits might have been dismissed in the Second Circuit due to lack of reasonable discovery. Under the LDP, courts would be able to dismiss section 10(b) and rule $10 \mathrm{~b}-5$ cases on the pleadings with greater confidence because plaintiffs will have received an opportunity for discovery consistent with the likelihood that they would succeed on the merits.

The LDP would confer these benefits at a relatively minor cost in judicial resources compared to the current Second Circuit standard. It would

91. Id.

92. Obviously, these costs will be non-trivial in absolute terms, especially in cases where many "players" were involved in the allegedly fraudulent transaction(s).

93. See In re Frank B. Hall \& Co. Secs. Litigation, 693 F. Supp. 1460 (S.D.N.Y. 1988) (defendant accounting firm submitted voluntarily to discovery of its workpapers).

94. See supra notes 61-69 and accompanying text. 
require no additional procedural layers, ${ }^{95}$ and the LDP would retain the Second Circuit enhanced pleading requirement's benefit of conserving judicial resources through deterrence and early dismissal of nuisance claims. Finally, the LDP would impose no new obligations on judges in terms of discovery rulings. Judges already make such "scope" rulings under rule 26(f) and would merely apply a similar standard here. ${ }^{96}$

The LDP would thus be consistent with the purposes of rule 9(b). The LDP clearly would "serve[] to minimize strike suits." provide further "assurance that the pleader has investigated the alleged fraud and reasonably believes that a wrong has occurred."98 The LDP would "serve[] to reinforce the basic notice function of pleadings under the Federal Rules." $" 98$ Finally, by deterring the filing of nuisance suits, the LDP would "protect [defendants'] reputations from unwarranted charges of fraud;" 100 this purpose is especially important where, as is often the case in section 10(b) and rule 10b-5 actions, "the defendants are professionals whose livelihood may depend on their reputation and the goodwill of their business in the community."101

The LDP also would be consistent with the purposes underlying the Securities Exchange Act of $1934^{102}$ as well as section $10(\mathrm{~b})$ and rule 10b-5. ${ }^{103}$ The LDP would not limit completeness or effectiveness of secur-

95. Rule $9(\mathrm{~b})$ hearings currently take place in all circuits, and at least one rule $26(\mathrm{f})$ conference is likely to occur at some point in the pre-trial stages of a class action, whether or not defendant moves to dismiss the action on rule 9(b) grounds. The LDP would merely advance the timing of the first rule $26(\mathrm{f})$ conference to an earlier stage in the proceedings.

96. The LDP is consistent with the current trend of conservation of judicial resources through case management. See FED. R. Crv. P. 16(a) advisory committee's note to 1983 amendment (case management is an express goal of pre-trial procedure).

97. 2A J. MOORE \& J. LuCAs, supra note 85, II 9.03[1], at 9-31 to -32 (2d ed. 1990) (citations omitted). The LDP by its very nature would serve to limit strike suits by limiting plaintiff's perceived litigation differential. See supra Section II(B).

98. 2A J. MOORE \& J. LuCAS, supra note 85, I 9.03[1], at 9-32 (2d ed. 1990) (citations omitted). The LDP would require plaintiff to detail the extent of her research, thereby allowing the court to assess both the extent of plaintiff's research and the reasonableness of her belief that a wrong has occurred.

99. Id. at $9-33$ (citations omitted). One goal of the LDP is to force plaintiff to provide defendant with enough information to prepare a response to the complaint and to apprise defendant fairly of the charge against her. See supra note 24.

100. 2A J. Moore \& J. LuCAS, supra note 85, II 9.03[1], at 9-31 (2d ed. 1990) (citations omitted); see supra note 24 .

101. 2A J. MOORE \& J. Lucas, supra note 85, II 9.03[1], at 9-31 (2d ed. 1990) (citations omitted).

102. "In enacting the $1934 \mathrm{Act}$, Congress stated that its purpose was 'to impose requirements necessary to make [securities] regulation and control reasonably complete and effective.' 15 U.S.C. \$ 78b." Herman \& MacLean v. Huddleston, 459 U.S. 375, 386 (1983). "Congress' aim in enacting the [Securities Exchange Act of 1934] was not confined solely to compensating defrauded investors. [It also] intended to deter fraud and manipulative practices in the securities markets . . ." Randall v. Loftsgaarden, 478 U.S. 647, 664 (1986).

103. The legislative history of $\$ 10(\mathrm{~b})$ is "bereft of any explicit explanation of Congress' intent." Ernst \& Ernst v. Hochfelder, 425 U.S. 185, 201 (1976). "As with Section 10(b), the administrative history of $10 \mathrm{~b}-5$ is so scant that courts have not often been guided by it." 5 A. JACOBS, Litigation and Practice Under Rule 10B-5, $\$ 5.02$, at $1-185$ (2d ed. 1989). Thus, one must look to judicial interpretations of the section and the rule to determine their purpose and scope.

Various courts have provided such interpretations. Section $10(\mathrm{~b})$ and rule $10 \mathrm{~b}-5$ "were intended to 
ities regulation and control and would not prevent the compensation of defrauded investors. Finally, the LDP would do little if anything to limit the deterrent effect of section 10 (b) or rule $10 \mathrm{~b}-5$.

\section{CONCLUSION}

The LDP, along with its elevated scienter pleading requirement, would be a narrowly tailored solution to the problem of nuisance litigation under section 10(b) and rule 10b-5. It would represent an improvement over the present system at two levels. First, the LDP would comport with the policies underlying rule $9(\mathrm{~b})$, section $10(\mathrm{~b})$, and rule $10 \mathrm{~b}-5$, and would advance important policy goals. ${ }^{104}$ It would effectively deter the initiation of nuisance suits ${ }^{105}$ and would be a useful tool for summarily dismissing those that are filed. ${ }^{106}$ It would strike at the economic roots of nuisance litigation while simultaneously allowing courts to dismiss nuisance lawsuits and claims at the pleading stage with a high degree of confidence that they are in fact nuisance suits. Moreover, this "gatekeeping" function would confer the added benefit of conserving the judicial resources now required to process nuisance suits. ${ }^{107}$ Finally, meritorious suits would still proceed, and thus the LDP would not lessen the deterrent effect of potential securities actions on corporate actors.

On a broader level, the LDP would increase public confidence in the legal system by preventing malefactors from avoiding liability on procedural grounds, while simultaneously preventing the waste of corporate assets by promoting summary dismissal of non-meritorious lawsuits. In the end, the LDP would promote efficient corporate operation by reducing the quantity of resources expended on the disposition of non-meritorious lawsuits.

provide a cause of action for any plaintiff who suffers an injury as a result of manipulative or deceptive practices made in connection with his or her sale or purchase of securities." Norris v. Wirtz, 719 F.2d 256, 258 (7th Cir. 1983), cert. denied, 466 U.S. 929 (1984) (citing Santa Fe Indus. v. Green, 430 U.S. 462, 476 (1977)). The purpose of $\$ 10(\mathrm{~b})$ and its accompanying rule

is to protect persons who are deceived in securities transactions-to make sure that buyers of securities get what they think they are getting and that sellers of securities are not tricked into parting with something for a price known to the buyer to be inadequate or for a consideration linown to the buyer not to be what it purports to be.

Chemical Bank v. Arthur Andersen \& Co., 726 F.2d 930, 943 (2d Cir. 1984) (Friendly, J.).

104. See supra Part III.

105. Sep supra notes 63-64 and accompanying text.

106. See supra note 69 and accompanying text.

107. See supra pp. 1602-03. 
